\title{
Growth and Topological Changes of Citrus limon (L.) Burm. f. 'Eureka' in Response to High Temperatures and Elevated Atmospheric Carbon Dioxide
}

\author{
Chris A. Martin and Jean C. Stutz \\ Department of Botany, Arizona State University, Box 871601, Tempe, AZ 85287-1601 \\ Bruce A. Kimball and Sherwood B. Idso \\ United States Water Conservation Laboratory, 4331 East Broadway, Phoenix, AZ 85040 \\ David H. Akey \\ United States Western Cotton Research Laboratory, 4135 East Broadway, Phoenix, AZ 85040
}

Additional index words. lemon, heat stress

\begin{abstract}
Growth and topological indices of 'Eureka' lemon were measured after 6 months in well-watered and wellfertilized conditions and factorial combinations of moderate $(29 / 21 \mathrm{C}$ day/night) or high $(42 / 32 \mathrm{C}$ day/night $)$ temperatures and ambient (350 to $380 \mu \mathrm{mol} \cdot \mathrm{mol}^{-1}$ ) or elevated (constant $680 \mu \mathrm{mol} \cdot \mathrm{mol}^{-1}$ ) $\mathrm{CO}_{2}$. In high temperatures, plants were smaller and had higher levels of leaf chlorophyll a than in moderate temperatures. Moreover, plants in high temperatures and elevated $\mathrm{CO}_{2}$ had about $15 \%$ higher levels of leaf chlorophyll a than those in high temperatures and ambient $\mathrm{CO}_{2}$. In high temperatures, plant growth in elevated $\mathrm{CO}_{2}$ was about $87 \%$ more than in ambient $\mathrm{CO}_{2}$. Thus, high $\mathrm{CO}_{2}$ reduced the negative effect of high temperature on shoot growth. In moderate temperatures, plant growth in elevated $\mathrm{CO}_{2}$ was only about $21 \%$ more than in ambient $\mathrm{CO}_{2}$. Irrespective of temperature treatments, shoot branch architecture in elevated $\mathrm{CO}_{2}$ was more hierarchical than those in ambient $\mathrm{CO}_{2}$. Specific shoot extension, a topological measure of branch frequency, was not affected by elevated $\mathrm{CO}_{2}$ in moderate temperatures, but was increased by elevated $\mathrm{CO}_{2}$ enrichment in high temperatures-an indication of decreased branch frequency and increased apical dominance. In moderate temperatures, plants in elevated $\mathrm{CO}_{2}$ had fibrous root branch patterns that were less hierarchical than at ambient $\mathrm{CO}_{2}$. The lengths of exterior and interior fibrous roots between branch points and the length of second-degree adventitious lateral branches were increased $>50 \%$ by high temperatures compared with moderate temperatures. Root length between branch points was not affected by $\mathrm{CO}_{2}$ levels.
\end{abstract}

High aerial temperatures can reduce plant growth by limiting external and internal carbon acquisition and use (Baker et al., 1988; Bar-Tsur et al., 1985; Levitt, 1980; Murtagh et al., 1987; Ranney and Peet, 1994). High aerial temperatures increase leaf-to-air vapor-pressure gradients, resulting in increased stomatal resistance to gas exchange (Syvertsen and Salyani, 1991) but high temperatures can also affect internal enzyme-catalyzed processes like ribulose-1,5-bisphosphate carboxylation-oxygenation, photosynthetic electron transport, or chloroplast membrane integrity (Berry and Bjorkman, 1980; Syvertsen and Lloyd, 1994). Furthermore, high root-zone temperatures such as those recorded in urban soils and container rooting media in outdoor production nurseries (Graves and Dana, 1987; Martin and Ingram, 1988) reduce plant growth and may decrease carbon assimilation by nonstomatal limitation of photosynthesis (Martin et al., 1989). The optimum temperature range for shoot and root growth of most citrus is 24 to 31C (Girton, 1927; Khairi and Hall, 1976). Shoot growth of 'Eureka' lemon was higher for plants grown at day/night temperature regimens of $25 / 15 \mathrm{C}$ than at $20 / 10 \mathrm{C}$ or $30 / 20 \mathrm{C}$ (Harty and Van Staden, 1988).

Elevated atmospheric $\mathrm{CO}_{2}$ can increase growth of $\mathrm{C}_{3}$ horticultural crops like citrus (Andersson, 1991; Eamus and Jarvis, 1989; Idso and Kimball, 1983, 1992; Koch et al., 1986), although the

Received for publication 27 Jan. 1995. Accepted for publication 7 June 1995. This research was funded in part by the U.S. Dept. of Energy, Carbon Dioxide Research Program, under interagency agreement DE-AI02-93ER61720. We gratefully acknowledge the technical assistance of Ron Seay and Tham Ngo Johnson in maintaining the $\mathrm{CO}_{2}$ and temperature treatments. The cost of publishing this paper was defrayed in part by the payment of page charges. Under postal regulations, this paper therefore must be hereby marked advertisement solely to indicate this fact. magnitude of this increase varies considerably with species, growing conditions, and exposure time (Lawlor and Mitchell, 1991). During the last decade, the interactive effects of air temperature and $\mathrm{CO}_{2}$ on plant growth have been investigated in several studies (Allen et al., 1990; Idso et al., 1987; Imai and Okamoto-Sato, 1991; McKee and Woodward, 1994; Mortensen, 1994). Results from

A

B
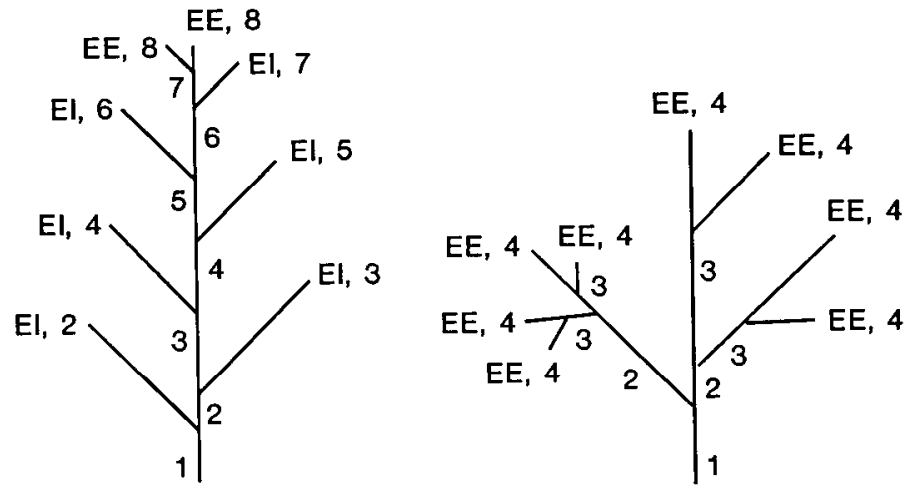

Fig. I Diagram showing distinctions between extreme topological patterns [(A) herringbone, (B) dichotomous] and illustration of the branch linkage terms used in this paper. $\mathrm{EE}=$ exterior-exterior linkages, $\mathrm{EI}=$ exterior-interior linkages, while interior linkages (II) are unlabelled. For each topological pattern, magnitude $(\mu)=8$ while values for altitude (a) and total pathlength $\left(p_{e}\right)$ are 8 and 43 , respectively, for $\mathbf{A}$, and 4 and 32, respectively, for $\mathbf{B}$. 
these studies suggest that the relative $\mathrm{CO}_{2}$-enhancement effect of growth caused by elevated $\mathrm{CO}_{2}$ might increase commensurate with increased temperature to at least 38C (Baker et al., 1994; Rawson, 1992), although we have found no studies about plant growth in response to elevated $\mathrm{CO}_{2}$ and supraoptimal temperatures $>38 \mathrm{C}$.

Architectural branch patterns of shoots and roots play a crucial role in a plant's adaptation to environmental factors by affecting light intensity and quality on leaves via canopy shading patterns and root uptake of water and nutrients via changes in the volume of soil explored and the density of roots within a given volume of soil (Ceulemans and Mousseau, 1994; Fitter, 1987). Architectural patterns of plants, roots in particular, display a degree of geometric plasticity to changes in environmental signals such as drought (Berntson and Woodward, 1992; Fitter, 1987) and low nutrient supply (Fitter and Strickland, 1991) independent of any effects on plant growth. Architectural branch patterns of plants have been quantified topologically (Fitter, 1987; Fitter et al., 1991; Werner and Smart, 1973). Topology is the study of geometric configurations of complex objects and, for plants, is not a function of shoot and root extension growth (Fitter, 1987).

In this paper we use the terminology presented by Fitter (1987) for identifying topological patterns of shoot and root branching (Fig. 1). Using this system, shoots and roots are comprised of a set of links of increasing developmental order. A link is a linear portion of a shoot or root between a meristem and the nearest branch point, two proximal branch points, or a branch point and the crown of the plant. Each link is either exterior, ending in a meristem, or interior, ending at another link. The base link of a shoot or root is the link most distal to an exterior link and has a developmental degree of one. Moving from the base link toward an exterior link, the developmental degree increases by the sum of each proximal link. The altitude $\left(a_{t}\right)$ of a root system is the longest path (the highest number of links) between the base link or crown and an exterior link. The total pathlength $\left(p_{e}\right)$ of a root system is the sum of all links for each path from the base link to each exterior link. The magnitude $(\mu)$ is the sum of all exterior links. As Fig. 1 illustrates, when magnitudes are equal, comparisons of values for altitude and total path length can aid in distinguishing differences in the geometric configuration of a root or shoot system. Additional information can be obtained by calculating the specific shoot extension [ratio of total shoot extension to magnitude $(\mu)$ ], which delineates branch frequency and branch link lengths, which indicate elongation. Interior branch links can be further classified into two subgroups, depending on whether adjoining links are exterior or interior (Smart, 1978). As such, each interior link can be categorized as exterior-interior (EI), interior links that adjoin other exterior links, or interior-interior (II), interior links that adjoin other interior links. Exterior branch links ending in a meristem are referred to as exterior-exterior (EE).

One clear topological study concerning elevated $\mathrm{CO}_{2}$ showed that elevated $\mathrm{CO}_{2}$ caused a more branched and elongated root system that foraged through larger volumes of soil (Berntson and Woodward, 1992). The effects of high temperature and the interactive effects of high temperature and elevated $\mathrm{CO}_{2}$ on woody plant architecture are unknown. The purpose of this study was to investigate the interactive effects of supraoptimal air and rootzone temperatures and elevated atmospheric $\mathrm{CO}_{2}$ on growth and topology of 'Eureka' lemon.

\section{Materials and Methods}

Growing conditions. Uniform rooted cuttings of 'Eureka' lemon (30-cm high) were potted on 2 Apr. 1993 into 27-liter polyethylene containers filled with a mixture of 1 Gilman loam soil : 4 coarse sand (by volume). Plants were then grown for 6 months in either of two, adjacent, identical glasshouses (north-south orientation, $10 \%$ light exclusion, similar absolute humidity) that provided moderate (29/21C day maximum/night minimum) or high (42/ $32 \mathrm{C}$ day maximum/night minimum) temperatures. Air temperatures in each glasshouse were computer controlled to oscillate diurnally between maximum and minimum points in a realistic sine wave pattern and deviated by $\pm 1 \mathrm{C}$ from the programmed temperatures. Typical leaf-to-air vapor-pressure gradients in the moderate and high temperature glasshouses ranged from 1.6 to 4.3 $\mathrm{kPa}$ during the early morning to 4.0 to $6.2 \mathrm{kPa}$ during midday as measured by a portable photosynthesis system [LI-6200; LI-COR, Lincoln, Neb.) with a cuvette chamber humidity sensor calibrated with a dewpoint-controlled water-vapor generator (LI-610). Rootzone temperatures were recorded by copper-constantan thermocouples attached to a micrologger (model 21X; Campbell Scientific, Logan, Utah). Thermocouple junctions were positioned at the center of the container rooting medium. Root-zone temperatures were similar to glasshouse air temperatures with similar sinusoidal patterns and amplitudes (data not shown). Furthermore, both glasshouses were partitioned in half with clear polyethylene plastic to separate an ambient (350 to $380 \mu \mathrm{mol} \cdot \mathrm{mol}^{-1}$ ) or enriched (constant $680 \mu \mathrm{mol} \cdot \mathrm{mol}^{-1}$ ) $\mathrm{CO}_{2}$ environment. The $\mathrm{CO}_{2}$ sampling control system used to monitor and regulate $\mathrm{CO}_{2}$-in-air mixtures was the same as described by Kimball et al. (1992).

Individual plants were fertilized at the start of the experiment and after 3 months by top dressing with $75 \mathrm{~g}$ of $20 \mathrm{~N}-0 \mathrm{P}-16.6 \mathrm{~K}$ (slow-release IBDU), $8 \mathrm{~g}$ of $0 \mathrm{~N}-19.6 \mathrm{P}-0 \mathrm{~K}$ (concentrated super-

Table 1. Canopy leaf, stem, and root dry weights and shoot-to-root ratio (SR) of 'Eureka' lemon plants after 6 months in 27-liter pots and exposure to factorial combinations of either moderate (29/21C day/night) or high (42/32C day/night) air and root-zone temperatures and ambient (350 to $\left.380 \mu \mathrm{mol} \cdot \mathrm{mol}^{-1}\right)$ or elevated $\left(680 \mu \mathrm{mol} \cdot \mathrm{mol}^{-1}\right) \mathrm{CO}_{2}$.

\begin{tabular}{|c|c|c|c|c|c|}
\hline \multirow[b]{2}{*}{ Temp (T) } & \multirow[b]{2}{*}{ Atmospheric $\mathrm{CO}_{2}$} & \multicolumn{3}{|c|}{ Dry wt (g/plant) } & \multirow[b]{2}{*}{ SR } \\
\hline & & Canopy leaf & Stem & Root & \\
\hline \multirow[t]{2}{*}{ Moderate } & Ambient & $23.8^{z}$ & 29.8 & 19.4 & 2.8 \\
\hline & Elevated & 31.1 & 33.7 & 23.6 & 2.8 \\
\hline \multirow[t]{2}{*}{ High } & Ambient & 12.6 & 11.3 & 5.5 & 4.4 \\
\hline & Elevated * & 22.7 & 21.7 & 10.7 & 4.2 \\
\hline \multicolumn{6}{|c|}{ Significance } \\
\hline $\mathrm{T}$ & & $* * *$ & $* * *$ & $* * *$ & $* * *$ \\
\hline $\mathrm{CO}_{2}$ & & $* * *$ & $* * *$ & $* * *$ & NS \\
\hline $\mathrm{T} \times \mathrm{CO}_{2}$ & & NS & $*$ & NS & NS \\
\hline
\end{tabular}

${ }^{2}$ Values are treatment means, $\mathrm{n}=15$

Ns,*,*****Nonsignificant or significant at $P \leq 0.05,0.01$, or 0.0001 . 


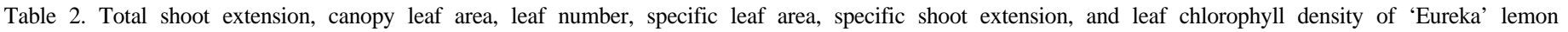
plants after 6 months in 27-liter pots and exposure to factorial combinations of either moderate (29/21C day/night) or high (42/32C day/night) air and root-zone temperatures and ambient $\left(350\right.$ to $\left.380 \mu \mathrm{mol} \cdot \mathrm{mol}^{-1}\right)$ or elevated $\left(680 \mu \mathrm{mol}^{-1} \mathrm{~mol}^{-1}\right) \mathrm{CO}_{2}$.

\begin{tabular}{|c|c|c|c|c|c|c|c|}
\hline Tcmp (T) & Atmosphcric $\mathrm{CO}_{2}$ & $\begin{array}{c}\text { Shoot } \\
\text { extensión } \\
\text { (m/plant) }\end{array}$ & $\begin{array}{c}\text { Canopy leaf } \\
\text { area } \\
\text { ( } \mathrm{m}^{2} / \text { plant) }\end{array}$ & $\begin{array}{c}\text { Leaf } \\
\text { no. }\end{array}$ & $\begin{array}{c}\text { Specific leaf } \\
\text { area } \\
\left(\mathrm{m}^{2} \cdot \mathrm{kg}^{-1}\right)\end{array}$ & $\begin{array}{c}\text { Specific } \\
\text { shoot extension } \\
\left(\mathrm{cm} / \mu^{2}\right)\end{array}$ & $\begin{array}{c}\text { Chlorophyll } a \\
\left(\mathrm{mg} \cdot \mathrm{m}^{-2}\right)\end{array}$ \\
\hline \multirow[t]{2}{*}{ Moderate } & Ambient & $0.25^{y}$ & 0.24 & 136 & 0.08 & 21.9 & 114 \\
\hline & Elevated & 0.29 & 0.28 & 142 & 0.06 & 20.2 & 103 \\
\hline \multirow[t]{2}{*}{ High } & Ambient & 0.15 & 0.14 & 88 & 0.10 & 20.6 & 164 \\
\hline & Elevated & 0.20 & 0.22 & 104 & 0.10 & 28.0 & 190 \\
\hline \multicolumn{8}{|c|}{ Significance } \\
\hline $\mathrm{T}$ & & $* * *$ & $* * *$ & $* *$ & $* * *$ & $*$ & $* * *$ \\
\hline $\mathrm{CO}_{2}$ & & $* *$ & $* *$ & NS & NS & NS & NS \\
\hline $\mathrm{T} \times \mathrm{CO}_{2}$ & & NS & NS & $*$ & NS & $* *$ & $* *$ \\
\hline
\end{tabular}

${ }^{2} \mu=$ Magnitude, the total number of external links.

${ }^{\mathrm{y}}$ Values are treatment means, $\mathrm{n}=15$.

Ns, $* * * * * *$ Nonsignificant or significant at $P \leq 0.05,0.01$, or 0.0001 .

phosphate), and $32 \mathrm{~g}$ of Micromax micronutrient fertilizer (GraceSierra, Milpitas, Calif.). Additionally, each plant was fertilized weekly with $4.4 \mathrm{M} \mathrm{H}_{3} \mathrm{PO}_{4}$ at $25 \mathrm{mg} \cdot \mathrm{liter}^{-1}$. Plants were irrigated every second day at $0400 \mathrm{HR}$ with about $1500 \mathrm{ml} /$ pot to prevent water stress.

Data collection. After 6 months of growth, leaf chlorophyll measurements were made with a hand-held chlorophyll meter (SPAD 502; Minolta Corp., Ramsay, N.J.) that measured the differential attenuation by leaves of light in wavebands centered near 650 and $980 \mathrm{~nm}$. Individual measurements were taken on six recently mature leaves per plant; these measurements were then averaged to produce a single mean value of chlorophyll $a$ density per plant. Leaves from all plants were separated from stems and counted, and leaf area was measured with a leaf area meter (LI3 100). Shoot extension of the remaining stems was measured with a ruler. For shoot canopy topology, a two-dimensional branch drawing of each shoot system was made on paper. On each drawing, the number of branch links was counted and each link was assigned a developmental order. Next, magnitude $(\mu)$, altitude $\left(a_{t}\right)$, total pathlength $\left(p_{e}\right)$, and specific shoot extension were calculated. Stems were then cut at the rooting medium surface, and root systems were carefully washed free of rooting medium by floating rootballs in a large water bath. The most developed, first-order adventitious root was excised from each root system at 30 consecutive branch links acropetal to the most terminal meristem. For these root samples, $\mu, a_{v}$ and $\mathrm{p}_{\mathrm{e}}$ were calculated after also tracing the root samples on paper and counting and ordering all branch links. Additionally, branch links for each root sample were categorized into groups of EE, EI, or II links (Fig. 1), and their lengths were measured. Also, five, second-degree lateral branches per each root sample were randomly selected and their lengths were measured. Finally, all leaves, stems and roots were oven-dried at $65 \mathrm{C}$ for 48 $\mathrm{h}$ and weighed.

Experiment design and data analysis. The experiment was a split-plot design arranged in a two temperature (main plot) $\times$ two atmospheric $\mathrm{CO}_{2}$ (subplot) factorial combination with 15 plants in each treatment combination. The general linear models procedure was used to test for significant responses and response interaction of all growth variables to treatments. For topological variables $a$, and $p_{e}$, a statistical analysis of treatment main effects and interactions for $\log$, transformed $a_{t}$ and $p_{e}$ was conducted by analysis of covariance using $\log _{10} \mu$ as the covariate. This was done to compensate for the strong positive correlation of $a_{t}$ and $p_{e}$ to $\mu$ (Bernston, 1994).When magnitude is constant, plants with higher values of $a_{t}$ and $p_{e}$ are more hierarchical than plants with lower values of $a_{t}$ and $p_{e}$ and visa versa. Because topology can also be characterized by the slopes of the log-linear relationships of $a_{t}$ and $p_{e}$ to $\mu$ (Fitter, 1987), linear models of $\log _{10} a_{v}$, (dependent variable) on $\log _{10} \mu$ (independent variable) and of $\log _{10} \mathrm{p}_{\mathrm{e}}$ on $\log _{10} \mu$ were calculated. If the slope coefficients of these regression equations approach a theoretical maximum $\left(\log _{10} a_{t}=1.0\right.$ and $\left.\log _{10} p_{e}=1.92\right)$ (Fitter and Strickland, 1991; Werner and Smart, 1973), then branch points of shoot and root systems are mostly limited to a main axis, with lateral branches patterned in two adjacent rows in mostly opposite directions. This topological pattern has been defined as herringbone (Fig. 1) (Fitter, 1987; Fitter and Strickland, 199 1). As the slope values decrease to a theoretical minimum $(\log$ !, $a_{t}=0.15$ and $\log _{10} p_{e}=1.02$ ), the branch pattern lacks a main axis and branching consists of a division into two parts. This topological pattern has been defined as dichotomous (Fitter, 1987; Fitter and Strickland, 1991). Intermediate branch patterns between herringbone and dichotomous extremes have been defined as random (Fitter, 1987; Fitter and Strickland, 1991).

\section{Results}

High temperatures generally suppressed lemon plant growth as demonstrated by lower leaf, stem, and root dry weights (Table 1); lower total shoot extension, canopy leaf area, and leaf number; and greater specific leaf area (Table 2, Fig. 2). The shoot-to-root ratio and leaf chlorophyll $a$ densities were higher for plants grown in high than moderate temperatures (Tables 1 and 2).

In contrast, elevated $\mathrm{CO}_{2}$ concentrations generally caused an increase in lemon plant growth demonstrated by greater leaf and roots dry weights (Table 1), total shoot extension, and canopy leaf area (Table 2, Fig. 2). There was no effect of $\mathrm{CO}$, enrichment on the shoot-to-root ratio of plants in either thermal environment (Table 1).

There was an interactive effect of $\mathrm{CO}_{2}$ and temperature on stem dry weight, leaf number, specific shoot extension, and leaf chlorophyll $a$ densities (Tables 1 and 2). Elevated $\mathrm{CO}_{2}$ had no effect on these variables when temperatures were moderate, but these variables were all increased in response to elevated $\mathrm{CO}_{2}$ at high temperatures. Elevated $\mathrm{CO}_{2}$ did not affect specific leaf area in either thermal environment, although, at moderate temperatures, leaves in elevated $\mathrm{CO}_{2}$ were slightly thicker than for those in ambient $\mathrm{CO}_{2}$ (Table 2).

The topology of 'Eureka' lemon shoots was predominately 


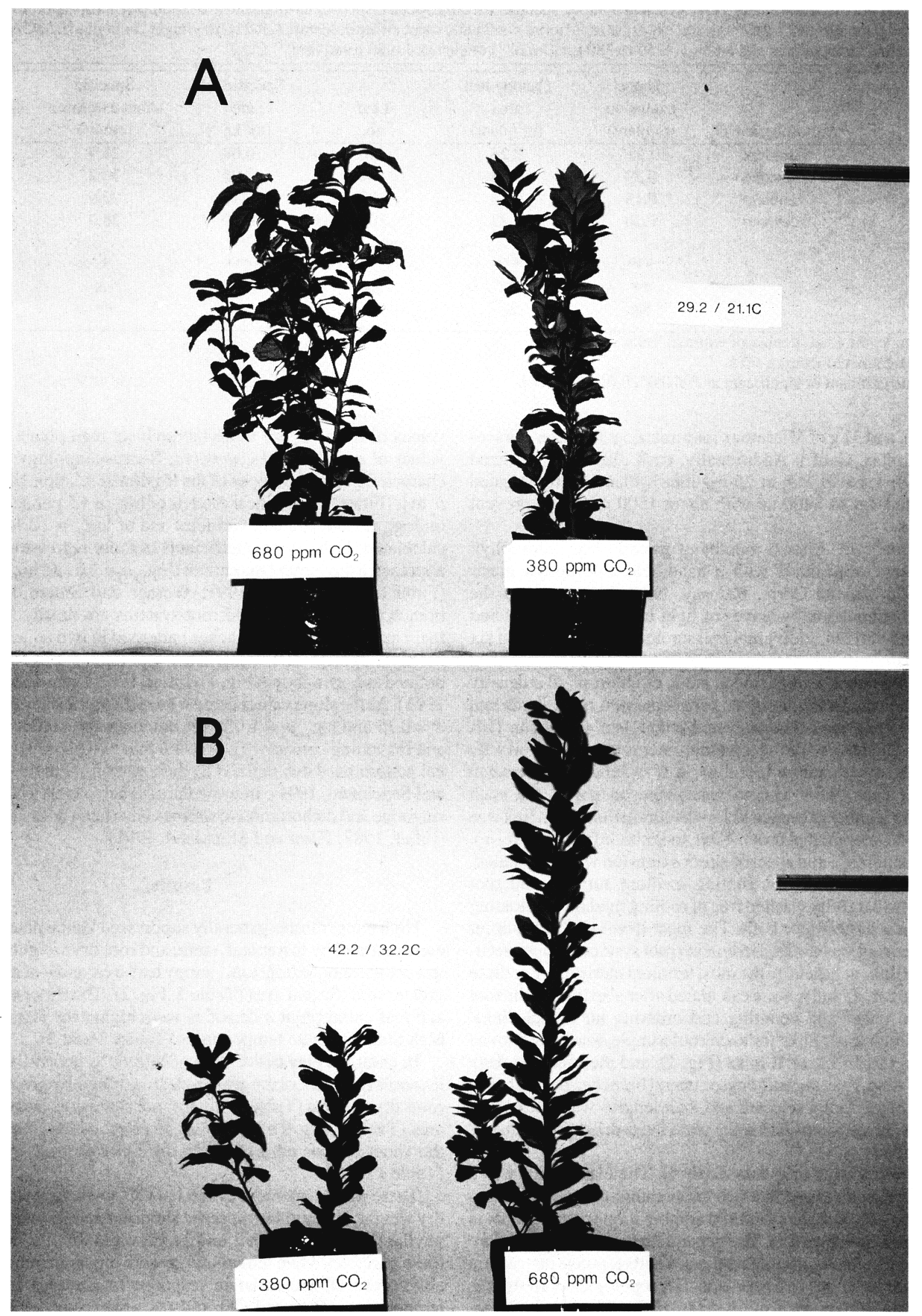

Fig. 2. 'Eureka' lemon plants after 6 months in 27-liter pots and exposure to factorial combinations of either moderate (29/21C day/night) or high (42/32C day/night) air and root-zone temperatures and ambient $\left(350\right.$ to $\left.380 \mu \mathrm{mol} \cdot \mathrm{mol}^{-1}\right)$ or elevated $\left(680 \mu \mathrm{mol} \cdot \mathrm{mol}^{-1}\right) \mathrm{CO}_{2}$. (A). Eureka lemon plants grown in moderate temperatures at elevated (left) or ambient $\mathrm{CO}_{2}$ (right). (B). Eureka lemon plants grown in high temperatures at ambient (left) or elevated $\mathrm{CO}_{2}$ (right). Since plants were positioned on the same surface, the horizontal bar is a point of reference depicting relative plant height. 
Table 3. Slopes of $\operatorname{logi}_{10} a_{t}$ (altitude) and $\log _{10} p_{e}$ (total pathlength) on $\log _{10} \mu$ (magnitude) for 'Eureka' lemon shoot canopies and fibrous roots after 6 months in 27-liter pots and exposure to factorial combinations of either moderate (29/21C day/night) or high $\left(42 / 32 \mathrm{C}\right.$ day/night) air and root-zone temperatures and ambient (350 to $\left.380 \mu \mathrm{mol} \cdot \mathrm{mol}^{-1}\right)$ or elevated $\left(680 \mu \mathrm{mol}^{-\mathrm{mol}^{-1}}\right) \mathrm{CO}_{2}$.

\begin{tabular}{|c|c|c|c|c|c|}
\hline \multirow[b]{2}{*}{ Temp } & \multirow[b]{2}{*}{ Atmospheric $\mathrm{CO}_{2}$} & \multicolumn{2}{|c|}{ Shoots } & \multicolumn{2}{|c|}{ Fibrous roots } \\
\hline & & $a_{t}$ & $p_{e}$ & $a_{t}$ & $p_{e}$ \\
\hline \multirow[t]{2}{*}{ Moderate } & $\Lambda$ mbient & $0.70 \pm 0.17$ & $1.46 \pm 0.12$ & $0.37 \pm 0.04$ & $1.33 \pm 0.05$ \\
\hline & Elevated & $0.87 \pm 0.19$ & $1.59 \pm 0.07$ & $0.13 \pm 0.07$ & $1.19 \pm 0.04$ \\
\hline \multirow[t]{2}{*}{ High } & Ambient & $0.70 \pm 0.12$ & $1.46 \pm 0.14$ & $0.24 \pm 0.10$ & $1.35 \pm 0.09$ \\
\hline & Elcvated & $0.98 \pm 0.12$ & $1.73 \pm 0.11$ & $0.26 \pm 0.03$ & $1.35 \pm 0.04$ \\
\hline
\end{tabular}

${ }^{2}$ Log-transformed topological benchmarks for dichotomous, random, or herringbone branching systems are 0.15 , 0.59 , or 1.00 , respectively, for $a_{t}$, and $1.02,1.52$, or 1.92, respectively, for $p_{e}$ (Werner and Smart, 1973). $a_{t}=$ The highest number of branch links between an external link and the base link or crown: $p_{e}=$ the sum of the number of branch links in all paths from all external links to the base link; $\mu=$ the total number of external links.

herringbone, while the topology of fibrous roots was predominately dichotomous, based on comparisons of the slopes of the loglinear relationships of $a$, and $p_{\mathrm{e}}$ to $\mu$ with the theoretical minimum and maximum (Table 3). Shoot topology was even more herringbone for plants grown in elevated $\mathrm{CO}_{2}$ compared to those in ambient $\mathrm{CO}$, (Table 3). At moderate temperatures, fibrous root topology of plants grown in elevated $\mathrm{CO}_{2}$ was even less dichotomous compared to those in ambient $\mathrm{CO}_{2}$, while elevated $\mathrm{CO}_{2}$ did not affect root topology in high temperatures (Table 3). Fibrous root EE and II link lengths were about 1.5 times longer and seconddegree adventitious root lateral branches were about 1.6 times longer in high than moderate temperatures (Table 4). Temperature treatments did not affect fibrous root EI linkage lengths. Carbon dioxide treatments had no affect on the length of fibrous root branch links or the length of secondary lateral adventitious roots.

\section{Discussion}

High aerial and rhizosphere temperatures of similar amplitude decreased growth of 'Eureka' lemon plants by about $50 \%$ and had a more negative effect on root than shoot growth. This negative effect on roots was shown by higher shoot-to-root ratios for plants in high temperatures compared to those in moderate temperatures. Plants in high temperatures had less shoot extension with fewer and thinner leaves that contained higher levels of chlorophyll a than those in moderate temperatures. Even though leaf chlorophyll a densities increased, reduced growth in high temperatures may have been caused in part by alterations in ribulose- 1,5-bisphosphate carboxylase/oxygenase (Rubisco) activity favoring oxygenation and the photorespiratory pathway over carboxylation of $\mathrm{CO}_{2}$ (Jordan and Ogren, 1984). High aerial temperatures also increased leaf to air vapor pressure gradients, which, for citrus leaves, has been positively correlated with stomata1 resistance to gas exchange and stomata1 limitation of photosynthesis (Syvertsen and Salyani, 1991).

Elevated $\mathrm{CO}_{2}$ caused about a $21 \%$ increase in growth when temperatures were moderate, an amount that was amplified to about $87 \%$ when temperatures were high. Leaves in high temperatures and elevated $\mathrm{CO}_{2}$ also had about $15 \%$ more chlorophyll a than those in high temperature and ambient $\mathrm{CO}_{2}$, an indication of higher leaf nitrogen content (Evans, 1989). Thus, high $\mathrm{CO}_{2}$ reduced the negative effects of high-temperature stress on shoot growth. The greater $\mathrm{CO}_{2}$-enhancement effect on 'Eureka' lemon plants in high temperatures could be due to increased nitrogen uptake by a larger root system. Other possible explanations for the greater $\mathrm{CO}_{2}$ enhancement effect are that Rubisco $\mathrm{CO}_{2} / \mathrm{O}_{2}$ specificity for oxygenation in high temperatures was changed to carboxylation by increased $\mathrm{CO}_{2}$ (Jordan and Ogren, 1984) or improved instanta- neous photosynthetic water-use efficiency caused by high $\mathrm{CO}_{2}$ suppression of stomatal conductance and enhancement of carbon assimilation (Eamus, 199 1). In moderate temperatures, the smaller $\mathrm{CO}_{2}$-enhancement effect may have been due to excessive accumulation of chloroplast photoassimilates. Plants in elevated $\mathrm{CO}_{2}$ and moderate to suboptimal temperatures have been reported to accumulate chloroplast photoassimilates (Farrar and Williams, 1991). This accumulation has recently been implicated in the repression of nuclear gene expression for chloroplast protein synthesis, which would lead to lower $\mathrm{CO}_{2}$ assimilation capacity (Van Oosten et al., 1994; Webber et al., 1994). Others have suggested that limitations of water or nutrients or restricted rooting volume in containers may reduce $\mathrm{CO}_{2}$ growth enhancement (Coleman et al., 1993; Long et al., 1992; McConnaughay et al., 1993; Thomas and Strain, 1991). In our study, all plants were well irrigated and well fertilized and visual inspections of all root systems at harvest time showed that no plants had pot-bound root systems.

Carbon dioxide enhancement of 'Eureka' lemon growth was not accompanied by a change in biomass allocation at either temperature treatment, which indicated that the entire plant benefited equally from an increase in carbon substrate. These findings are consistent with those of Sionit et al. (1985) on Liquidumber styraciflua and Pinus taeda and a recent literature survey of herbaceous and woody plants under nonlimiting conditions for water and nutrients (Stulen and den Hertog, 1993). Our observed increase in 'Eureka' lemon canopy leaf area with $\mathrm{CO}_{2}$ enrichment agrees with a survey of literature by Ceulemans and Mousseau (1994), who noted that elevated $\mathrm{CO}_{2}$. promoted an increase in total leaf area, especially under well-fertilized conditions in most woody species. In our study, the increase in canopy leaf area was due to a greater individual leaf area when temperatures were moderate and an increased number of leaves when temperatures were high.

Irrespective of temperature treatments, 'Eureka' lemon plants in elevated $\mathrm{CO}_{2}$ had a more herringbone shoot branching pattern

Table 4. Exterior-exterior (EE), interior-interior (II), and exterior-interior (EI) link lengths and the length of second-degree lateral branches of 'Eureka' lemon fibrous roots after 6 months in 27-liter pots and exposure to either moderate (29/21C day/night) or high (42/32C day/ night) air and root-zone temperatures.

\begin{tabular}{|c|c|c|c|c|c|c|}
\hline \multirow[b]{2}{*}{ Temp } & \multicolumn{3}{|c|}{ Link length (mm) } & \multirow[b]{2}{*}{$2^{\circ}$ lateral } & \multirow[b]{2}{*}{ length } & \multirow[b]{2}{*}{ (mm) } \\
\hline & $\mathrm{EE}$ & E I & II & & & \\
\hline Moderate & $18.8^{2}$ & 14.4 & 5.2 & & 54.8 & \\
\hline High & 28.0 & 12.5 & 8.2 & & 90.0 & \\
\hline Significance & $* * *$ & N S & $* *$ & & $* * *$ & \\
\hline
\end{tabular}

${ }^{2}$ Values are treatment means, $\mathrm{n}=30$.

Ns $*, * *, * * *$ Nonsignificant or significant at $P \leq 0.05,0.01$, or 0.0001 . 
than those in ambient $\mathrm{CO}_{2}$. This effect was visibly evident in high temperatures (Fig. 2) and was also quantified by lower branch frequency (high specific shoot extension), an indication of increased apical dominance. Few studies have examined the effect of $\mathrm{CO}_{2}$ on shoot branch patterns, and, to our-knowledge, no studies have examined the effect of $\mathrm{CO}_{2}$ on shoot topology. Elevated $\mathrm{CO}_{2}$ increased the number of shoot lateral branches of sweet gum (Sionit et al., 1985) and affected canopy shape and height of several tropical trees (Reekie and Bazzaz, 1989); however, it was not clear whether these responses were actual changes in shoot topology or merely a $\mathrm{CO}_{2}$-enhancement effect on growth because topological analyses were not conducted. On the canopy level, it would seem to us that a herringbone topology may benefit citrus canopies by limiting self-shading.

Fibrous roots of plants in elevated $\mathrm{CO}_{2}$ were more dichotomous than for those in ambient $\mathrm{CO}_{2}$ when air and root-zone temperatures were moderate. This response was similar to that reported by Bernston and Woodward (1992), who performed their experiments with Senecio vulgaris at $22 \mathrm{C}$ day/12C night. Since a dichotomous root system has a higher transport efficiency of water and nutrients than a herringbone system because of a shorter distance between the point of absorption and the shoot (Bernston, 1994), changes to a dichotomous root topology may be a critical response of a plant to meet the demand for increased nutrients in an elevated $\mathrm{CO}_{2}$ environment. However, we also show that root topology did not respond to elevated $\mathrm{CO}_{2}$ when temperatures were high and that plants in high temperatures had smaller but more elongate root systems than those in moderate temperatures. In the case of high temperatures, root systems of plants in elevated $\mathrm{CO}_{2}$ may be responding to the demand for increased nutrients by becoming larger and exploring a greater soil volume rather than acclimating topologically.

\section{Literature Cited}

Allen, S.G., S.B. Idso, B.A. Kimball, J.T. Baker, L.H. Allen, Jr., J.R. Mauney, J.W. Radin, and M.G. Anderson. 1990. Effects of air temperature on atmospheric $\mathrm{CO}_{2}$-plant growth relationships. U.S. Dept. of Energy, Carbon Dioxide Research Program and U.S. Dept. of Agriculture-Agricultural Research Service, Washington, D.C. Rpt. TR048. DOE/ER-0450T

Andersson, N.E. 1991. The influence of constant and diurnally changing $\mathrm{CO}_{2}$ concentrations on plant growth and development. J. Hort. Sci. 66:569-574.

Baker, D.A., S.P. Long, and D.P. Ott. 1988. Photosynthesis and temperature, with reference to effects on quantum yield. Symp. Soc. Expt. Biol. 42:347-376.

Baker, J.T., S.L. Albrecht, D. Pan, L.H. Allen, Jr., N.B. Pickering, and K.J. Boote. 1994. Carbon dioxide and temperature effects on rice (Oyrza sativa L., cv. 'IR-72'). Proc. Soil Crop Soc. Fla. 53:90-97.

Bar-Tsur, A., J. Rudich, and B. Bravdo. 1985. High temperature effects on $\mathrm{CO}_{2}$ gas exchange in heat-tolerant and sensitive tomatoes. J. Amer. Sci. Hort. Sci. 110:582-586.

Bernston, G.M. 1994. Modelling root architecture: are there tradeoffs between efficiency and potential of resource acquisition? New Phytol. 127:483-493.

Bernston, G.M. and F.I. Woodward. 1992. The root system architecture and development of Senecio vulgaris in elevated $\mathrm{CO}_{2}$ and drought. Func. Ecol. 6:324-333

Berry, J. and 0. Bjorkman. 1980. Photosynthegc response and adaptation to temperature in higher plants. Annu. Rev. Plant Physiol. 31:491-543.

Coleman J.S., K.D.M. McConnaughay, and F.A. Bazzaz. 1993. Elevated $\mathrm{CO}_{2}$ and plant nitrogen use: Is reduced tissue nitrogen concentration size-dependent? Oecology 93:195-200.

Ceulemans, R. and M. Mousseau. 1994. Tansley review no. 71 effects of elevated atmospheric $\mathrm{CO}_{2}$ on woody plants. New Phytol. 127:425-446.
Eamus, D. 1991. The interaction of rising $\mathrm{CO}_{2}$ and temperatures with water use efficiency. Plant Cell Environ. 14:843-852.

Eamus, D. and P.G. Jarvis. 1989. The direct effects of increase in the global atmospheric $\mathrm{CO}_{2}$ concentration on natural and commercial temperate trees and forests. Adv. Ecol. Res. 19:2-55.

Evans, J.R. 1989. Photosynthesis and nitrogen relationships in leaves of $\mathrm{C}_{3}$ plants. Oecology 78:9-19.

Farrar, J.F. and M.L. Williams. 1991. The effects of increased atmospheric carbon dioxide and temperature on carbon partitioning, sourcesink relations and respiration. Plant Cell Environ. 14:819-830.

Fitter, A.H. 1987. An architectural approach to the comparative ecology of plant root systems. New Phytol. 106:61-77.

Fitter, A.H. and T.R. Strickland. 1991. Architectural analysis of plant root systems. II. Influence of nutrient supply on architecture in contrasting plant species. New Phytol. 118:383-389.

Fitter, A.H., T.R. Strickland, M.L. Harvey, and G.W. Wilson. 1991. Architectural analysis of plant root systems. I. Architectural correlates of exploitation efficiency. New Phytol. 118:375-382.

Girton, R.E. 1927. The growth of citrus seedlings as influenced by environmental factors. Univ. Calif. Publ. Agr. Sci. 5:83-117.

Graves, W.R. and M.N. Dana. 1987. Root-zone temperatures monitored at urban sites. HortScience 22:613-614.

Harty, A.R. and J. Van Staden. 1988. Paclobutrazol and temperature effects on lemon. Proc. 6th Intl. Citrus Congr. 1:343-352.

Idso, S.B., B.A. Kimball, M.G. Anderson, and J.R. Mauney .1987. Effects of atmospheric $\mathrm{CO}_{2}$ on plant growth: The interactive role of temperature. Agr. Ecosys. Environ. 20: 1-10.

Idso, S.B. and B.A. Kimball. 1992. Aboveground inventory of sour orange trees exposed to different atmospheric $\mathrm{CO}_{2}$ concentrations for 3 full years. Agr. For. Meteorol. 60:145-1 51.

Imai, K. and M. Okamoto-Sato. 1991. Effects of temperature on $\mathrm{CO}_{2}$ dependence of gas exchange in $\mathrm{C}_{3}$ and $\mathrm{C}_{4}$ crop plants. Jpn. J. Crop Sci. 60:139-145.

Jordan, D.B. and W.L. Ogren. 1984. The $\mathrm{CO}_{2} / \mathrm{O}_{2}$ specificity of ribulose 1,5-bisphosphate carboxylase/oxygenase. Planta 161:308-313.

Khairi, M.M.A. and A.E. Hall. 1976. Effects of air and soil temperatures on vegetative growth of Citrus. J. Amer. Soc. Hort. Sci. 101:337-341.

Kimball, B.A. 1983. Carbon dioxide and agricultural yield: An assemblage and analysis of 430 prior observations. Agron. J. 75:779-788.

Kimball, B.A., J.R. Mauney, R.L. LaMorte, G. Guinn, F.S. Nakayama, J.W. Radin, E.A. Lakatos, S.T. Mitchell, L.L. Parker, G.J. Peresta, P.E. Nixon III, B. Savoy, S.M. Harris, R. MacDonald, H. Pros, and J. Martinez. 1992. Carbon dioxide enrichment: Data on the response of cotton to varying $\mathrm{CO}_{2}$, irrigation, and nitrogen. ORNL/CDIAC-44, NPD-037, Oak Ridge Natl. Lab., Oak Ridge, Tenn.

Koch, K.E., P.H. Jones, W.T. Avigne, and L.H. Allen. 1986. Growth, dry matter partitioning, and diurnal activities of RuBP carboxylase in citrus seedlings maintained at two levels of $\mathrm{CO}_{2}$. Physiol. Plant. 67:477-484.

Lawlor, D.W. and R.A.C. Mitchell. 1991. The effects of increasing $\mathrm{CO}_{2}$ on crop photosynthesis and productivity: a review of field studies. Plant Cell Environ. 14:807-818.

Levitt, J. 1980. Response of plants to environmental stress. vo1 1. Chilling, freezing and high temperature stresses. Academic Press, New York.

Long, S.P. 199 1. Modification of the response of photosynthetic productivity to rising temperature by atmospheric $\mathrm{CO}_{2}$ concentration: Has its importance been underestimated? Plant, Cell Environ. 14:729-740.

Martin, C.A. and D.L. Ingram. 1988. Temperature dynamics in black poly containers. Southern Nurseryman Res. Conf. 33:71-74.

Martin, C.A., D.L. Ingram, and T.A. Nell. 1989. Supraoptimal root-zone temperature alters growth and photosynthesis of holly and elm. J. Arbor. 15:272-276.

McConnaughay, K.D.M., G.M. Bemtson, and F.A. Bazzaz. 1993. Limitations to $\mathrm{CO}_{2}$-induced growth enhancement in pot studies. Oecology 94:550-557.

McKee, I.F. and F.I. Woodward. 1994. $\mathrm{CO}_{2}$ enrichment responses of wheat: Interactions with temperature, nitrate and phosphate. New Phytol. 127:447453.

Mortensen, L.M. 1994. Effects of elevated $\mathrm{CO}_{2}$ concentrations on growth and yield of eight vegetable species in a cool climate. Sci. Hort. 58:177- 
185.

Murtagh, G.J., E.A. Halligan, and D.H. Greer. 1987. Components of growth and darkrespiration of kikuyu (Pennisetum clundestinum Chiov.) at various temperatures. Ann. Bot. 59:149-157.

Ranney, T.G. and M.M. Peet. 1994. Heat tolerance of five taxa of birch (Betula): Physiological responses to supraoptimal leaf temperatures. J. Amer. Soc. Hort. Sci. 119:243-248.

Rawson, H.M. 1992. Plant response to temperature under conditions of elevated $\mathrm{CO}_{2}$. Austral. J. Bot. 40:473-490.

Reekie, E.G. and F.A. Bazzaz. 1989. Competition and patterns of resource use among seedlings of five tropical trees grown at ambient and elevated $\mathrm{CO}_{2}$. Oecology 79:212-222.

Sionit, N., B.R. Strain, H. Hellmers, G.H. Riechers, and C.H. Jaeger. 1985. Long-term atmospheric CO, enrichment affects the growth and development of Liquidambar styraciflua and Pinus taeda seedlings. Can. J. For. Res. 15:468-471.

Smart, J.S. 1978. The analysis of drainage network composition. Earth Sur. Pro. 3:129-170.

Stulen, I. and J. den Hertog. 1993. Root growth and functioning under atmospheric $\mathrm{CO}_{2}$ enrichment. Vegetation 104/105:99-115.

Syvertsen, J.P. and J.J Lloyd. 1994. Citrus, p. 65-99. In: B. Schaffer and PC. Andersen (eds.). Handbook of environmental physiology of fruit crops. vol. 2. Sub-tropical and tropical fruits. CRC Press, Salem, Mass. Syvertsen, J.P. and M. Salyani. 1991. Petroleum spray oil effects on net gas exchange of grapefruit leaves at various vapor pressures. HortScience 26:168-170.

Thomas, R.B. and B.R. Strain. 1991. Root restriction as a factor in photosynthetic acclimation of cotton seedlings grown in elevatedcarbon dioxide. Plant Physiol. 96:627-634.

Van Oosten J.-J., D. Wilkins, and R.T. Besford. 1994. Regulation of the expression of photosynthetic nuclear genes by $\mathrm{CO}_{2}$ is mimicked by regulation by carbohydrates: A mechanism for the acclimation of photosynthesis to high $\mathrm{CO}_{2}$. Plant Cell Environ. 17:913-923.

Webber A.N., G-Y Nie, and S.P. Long. 1994. Acclimation of photosynthetic proteins to rising atmospheric $\mathrm{CO}_{2}$. Photosyn. Res. 39:413-425. Werner, C. and J.S. Smart. 1973. Some new methods of topological classification of channel networks. Geol. Anal. 5:271-295. 